\title{
Innovation Adoption in Mexican Small Family Firms
}

\author{
Sandra Yesenia Pinzón-Castro ${ }^{1}$, Gonzalo Maldonado-Guzmán ${ }^{1}$, \& José Trinidad Marín-Aguilar ${ }^{1}$ \\ ${ }^{1}$ Centro de Ciencias Económicas y Administrativas, Universidad Autonoma de Aguascalientes, Mexico \\ Correspondence: Gonzalo Maldonado-Guzman, Centro de Ciencias Económicas y Administrativas, Universidad \\ Autonoma de Aguascalientes, Aguascalientes, Mexico, Avenida Uni versidad No. 940, Ciudad Uni versitaria, C.P. \\ 20131, Mexico.
}

Received: January 23, 2018

Accepted: February 14, 2018

Online Published: February 23, 2018

doi:10.5539/ibr.v11n4p7

URL: https://doi.org/10.5539/ibr.v11n4p7

\begin{abstract}
Innovation is a topic that has been widely analyzed and discussed in the literature of business and management sciences and there a far and wide consensus among scholars, researchers and professionals that innovation activities should be considered not only as a business strategy but also as a daily activity in enterprises, especially in small and medium-sized ones. However, a high percentage of theoretical and empirical published investigations have focused in the innovation activities of big enterprises while only a small percentage has analyzed this construct in small and medium-sized enterprises. Only a few of them have focused in small, family-owned enterprises even when this type of business is the most representative of the economy and society in country around the world. Therefore, the main goal of this empirical research is the analysis of adopting innovation activities in small, family-owned businesses in an emerging country, as it is the case of Mexico. The results obtained show that there is a clear adoption of innovation in products, processes and management systems from small family businesses.
\end{abstract}

Keywords: innovation adoption, family firms, small business

\section{Introduction}

There is an extensive publication of theoretical and empirical researches in the current literature of business and management sciences that has analyzed and discussed at length the characteristics and return of enterprises regarding innovation activities (Lodh, Nandy \& Chen, 2014). However, relatively few investigations have analyzed the existing relation between small family businesses and innovation activities (Craig \& Moores, 2006). Only a few of them have focused in countries with emerging economies (as it is the case of Mexico) even when the globalization of the economy and markets provide several opportunities for family businesses to adopt and implement innovation activities. Such activities allow them not only to improve their level of competitiveness but also to survive in the long run (Aghion, Burgess, Redding \& Ziliboti, 2005).

Similarly, there is a general consensus in the literature that family businesses are the most common type of enterprise that exist in the economy and society in developed countries, those with emerging economies and developing ones. There is an extensive literature that has analyzed and discussed the importance of the owner of family businesses Villalonga \& Amit, 2006) but there is a void in the literature regarding investigations that analyze the importance of innovation in small family businesses (Lodh et al., 2014). Thus, the scarce research studies have found positive and significant results in both de veloped countries (Kim, Kim \& Lee, 2008; Chen \& Hsu, 2009) as well as countries with an emerging economy and developing ones (Sirmon, Arregle, Hitt \& Webb, 2008; Block, 2012).

Accordingly, in a recent investigation by Le Breton-Miller, Miller and Lester (2011) found contradictory evidence in the investment made in innovation activities by small family businesses. As a result, these authors concluded that the managers and/or owners of family enterprises usually adopt conservative strategies, which provide them with regular returns and restrict too much the investment in innovation activities because of the fear of taking risks and preferring always the comfort zone of their investment (Le Breton-Miller et al., 2011). Moreover, in a previous research, James (1999) had already considered that the managers and/or owners of small family enterprises sacrifice their personal interest to invest more economic resources in innovation activities in order to improve the financial capacity of enterprises.

Nonetheless, in developing countries and with an emerging economy, there is usually no protection of 
investments, an inefficient judicial system, a weak protection of intellectual property, a legal system with high levels of corruption, underdeveloped capital markets and many other limitations that force family business to focus in obtaining a higher level of business return rather than adopting innovation activities (Khanna \& Palepu, $2000 \mathrm{a}, \mathrm{b})$ even when it has been widely acknowledged in the literature that the adoption and implementation of innovation activities allow enterprises to increase significantly their level of return as well as the value addition of their products (Blundell, Griffith \& Van Reenen, 1999; Cho \& Puick, 2005).

In this regard, some of the investigations published in the literature that link small family businesses and innovation activities have been able to do it from the perspective of external resources (Sirmon \& Hitt, 2003) or from the perspective of the agency (Morck \& Yeung, 2003; Choi, Lee \& Willliams, 2011) but there are not studies that have considered the perspective of the adoption of innovation activities. That is why it is necessary to increase the theoretical and empirical evidence of the adoption of innovation activities in small family businesses from this perspective (Laforet, 2013; Lodh et al., 2013; Brines, Shepherd \& Woods, 2013). Therefore, the main contribution of this empirical research is the analysis and discussion of the adoption of innovation activities in small family businesses in a country with an emerging country, which is the case of Mexico, as it suggests Laforet (2013), Lodh et al. (2014) and Brines et al. (2013).

\section{Method}

In the literature of business and management sciences, there is a wide debate among researchers, scholars, and professionals about the conceptualization of family business and there is still no agreement regarding a clear and precise definition (Wortman, 1994; Upton \& Heck, 1997; Upton, Teal \& Felan, 2001) despite it had already been established that in order to define a family enterprise it should have a series or requirements in order to be considered one of them (Handler, 1994; Litz, 1995). Additionally, Sharma, Chrisman and Chua (1997) concluded that the essential aspects that family enterprises should have is that the managers are the owners and have the control of the organization, the family must have a strong influence in making decisions and there must be a control transfer of the enterprise to the next family generations.

Similarly, there is in the current literature an important interest from researchers, scholars and professionals about the study and analysis of the continuous growth of small family businesses in the economy and society of any country (Sharma, 2004) as well as the creation of knowledge that is producing this important type of enterprise (Brouthers, Andriessen \& Nicoleas, 1998; Richbell, Watts \& Wardle, 2006; Le Breton-Miller \& Miller, 2008). There is mostly an increasing interest in two transcendental topics: the analysis of the level of entrepreneurism of small family businesses and the importance of innovation activities (Kraus, Pohjola \& Koponen, 2012) since innovation activities have been acknowledged in the literature as a way to exploit the new opportunities that the market offers to improve the results of enterprises (Zahra, 2005; Craig \& Moores, 2006; Naldi, Nordqvist, Sjoberg \& Wklund, 2007; Kellermanns, Eddleston, Sarathe \& Murohy, 2012).

In this regard, there are few published investigations in the current literature that have explored the importance of the adoption of innovation activities inside small family businesses (Litz \& Kleysen, 2001; Gudmundson, Hartman \& Tower, 2003; Craig \& Dibrell, 2006; Kellermanns \& Eddleston, 2006; Craig \& Moores, 2006; McAdam, Reid \& Mitchell, 2010; Kellermanns et al., 2012) although this topic has increased its publication because of the special edition that the Journal of Small Business Economics dedicated to the analysis and discussion of entrepreneurism of family businesses and particularly the importance of innovation in this type of enterprise (Kellermanns et al., 2012).

Additionally, there is theoretical and empirical evidence in the current literature of business and management sciences that establishes the presence of significant differences in the adoption of innovation activities between family businesses and those who are not family-owned (Kraus et al., 2012) and these differences are emphasized even more when a comparison is made between small family businesses and bigger family businesses (Brines et al., 2013).This is why Sharma and Salvato (2011: 1200) made the following question: "What factors are the ones that influence more in family businesses so they adopt and implement as soon as possible the innovation activities?"

Several researchers, scholars and professionals have tried to answer this question by means of the enterprise orientation (Nordqvist, Habbershon, \& Melin, 2008; Zellweger, Muhlebach \& Sieger, 2010), of the resources and skills that family business have in order to create or inhibit entrepreneurism and innovation activities (Sirmon \& Hitt, 2003) and of the effects of the notion of family business that managers or owners have about them (Dyer, 2006; Habbershon, 2006). However, according to Habbershon, Williams and MacMillan (2003) as well as Habberson (2006), the social capital created by the notion of the manager or owner of the family business will be the transcendental element for the entrepreneurial behavior and the innovation capacity of the family business.

In a more recent investigation, Patel and Fiet (2011) concluded that family businesses have particularly a lot 
more advantages than those that are not family-owned regarding the exploitation of new opportunities provided by an increasingly globalized and competitive market. This is because of the same characteristics that this type of enterprises has such as the long-term orientation of the control from the family, the scarce rotation of staff and managers, the ease of making decisions from managers or owners and the replacement of executives (Patel \& Fiet, 2011). This allows family businesses, especially the small ones, to create a working environment and dynamic that favors the adoption of innovation activities (Brines et al., 2013).

In this regard, the family business is the most dominant industry in any country of the world, but it is specifically bigger in developing and emerging economy countries (La Porta, López-de-Salinas \& Shleifer, 1999) since it is precisely this type of countries where family businesses take the form of small family enterprises which provide employment to thousands of workers and employees. These businesses also contribute more to the development of economy and society (Lodh et al., 2014). Consequently, several investigations have proved that over a third of the 500 most important enterprises in S\&P ranking (Anderson \& Reeb, 2003) and the top 500 enterprises of the ranking of Fortune (Shleifer \& Vishny, 1986) are precisely family businesses.

Furthermore, the structure of the companies in the emerging and de veloping countries is usually through the control of a specific family (Manikutty, 2000). This can have effects that are particularly positive and significant in innovation activities because family businesses have precisely different advantages in comparison to other types of enterprises such as the control of investment in research and development activities, the achievement of economies of scale, the control of management from a person, a fast decision-making and the change to the adjustment of products to the needs and demand of the market. These are some of the essential elements to achieve a more efficient and effective adoption and implementation of innovation activities (Lodh et al., 2014).

Nonetheless, it has been established in the literature that small family businesses usually have several problems of stakes among the family members that have control of the enterprise (La Porta et al., 1999). But then again it also has been proved that the leadership of the owner or manager of the enterprise, commonly the father of the family who has the control of the business, is essential so the organizations is in better conditions to adopt innovation activities by making all the family members to work as a team not only to decrease the organization problems but also to optimize in the best possible way the human, economic and financial resources to increase the innovation activities (Belloc, 2012).

Similarly, it has also been established in the literature that family businesses have several advantages. The most important one is the control of the company by one family because it can involve the whole family in the activities of the organization, especially when the manager or owner of the business has made the decision of adopting inno vation activities. This allows enterprises to achieve a higher level of growth, increase their level of technological innovation, improve their market position, increase significantly their business return and survive in the market in which they participate for a long period of time (Anderson \& Reeb, 2003; Le Breton-Miller et al., 2011).

In a similar trend, some studies published in the current literature, which have focused in small family businesses of countries with emerging economies, have found out in general terms that the knowledge and the investment in research and development promote and increase significantly the innovation activities of enterprises. Accordingly, an important percentage of these small family businesses tend to invest a higher amount of economic resources when they obtain satisfactory results with the adoption of innovation activities (Block, 2012). However, Simon et al. (2008) concluded that when family businesses use a higher percentage of investment in activities of investment and development, they achieve a high level of business return which is similar to those enterprises that are not family-owned but the level of innovation decreases depending on the fact that the manager or owner of the business can involve the whole family in the organization.

In a different research, Kim et al. (2008) found out that when the family members get involved more in the organization, there are higher possibilities of increasing the investment in research and de velopment projects in the long term in comparison to enterprises that are not family-owned. On the other hand, Ayyagari, Demirgüç-Kunt and Maksimovic (2011) analyzed 19,000 family businesses from 47developing countries and concluded that family enterprises achieve better results in their innovation activities when the family members get involved in both decision-making and the development of such innovation activities.

In this regard, the working dynamic and involvement of the family members in the organization, combined with the resources and skills that small family businesses have, produce different characteristics that can differentiate this type of enterprises from the others (Chua, Chrisman \& Sharma, 1999; Astrachan, 2010) creating with these higher levels of innovation (Brines et al., 2013). Thus, the combination of family with the small enterprise creates a positive and significant influence in the innovation of products, processes and management systems (Litz \& 
Kleysen, 2001; Salvato, 2004; Zahra, 2005; Kellermanns et al., 2008) since the innovation in products, processes and management systems carried out by small family businesses decrease significantly production costs which can help to increase the price of new products that are obtained by clients and consumers (Cohen \& Klepper, 1996).

For this reason, the structure of the family business will be an important element that will determine, on one hand, the entrepreneurial activities (Cramer, 2002) and, on the other hand, the innovation activities in products, processes and management systems (Lee \& O'Neill, 2003; Lima, 2010). Consequently, the innovation in small family businesses is the result of the creation of new ide as of the family (Emmendoerfer \& Halal, 2008), which produce more and better results in the innovation activities in products, processes and management systems (Brines et al., 2013; Lodh et al., 2014). Therefore, considering the information presented above it is possible to state at this point the following hypotheses:

\section{H1: The higher the innovation in products, the higher the level of innovation activities}

H2: The higher the innovation in processes, the higher the level of innovation activities

\section{H3: The higher the innovation in management systems, the higher the level of innovation activities}

\subsection{Sampling Procedures}

In order to answer the stated hypotheses, an empirical research was made by taking into consideration the small family businesses located in Aguascalientes State (Mexico) by using the 2014 directory of the Sistema de Información Empresarial Mexicano (System of Mexican Business Information, or SIEM) as a reference framework. The directory had a total of 7,662 registered enterprises and the ones considered for the research were those that had between 5 and 250 workers (1,342 enterprises) which produced a produced a sample of 400 enterprises that represented slightly over $30 \%$ of all the enterprises. Similarly, a questionnaire was applied as a personal interview to managers of a sample of 400 SMEs that were selected randomly with a maximum error of $\pm 4.5 \%$ and a reliability level of $95 \%$. From all the questionnaires obtained, 296 are considered as small family businesses and 104 as not family-owned enterprises so the final sample for this research was 296 family businesses.

\subsection{Measures and Covariates}

In order to measure the innovation activities, managers were asked to indicate if the enterprise had carried out innovation activities in the last two years. To measure the importance of the innovations, the managers were asked to evaluate the innovation in products, processes and management systems by using seven items measured by means of a five-point Likert scale (from $1=$ not important at all to $5=$ very important as its limits) that was adapted from Zahra and Covin (1993), Kalantaridis and Pheby (1999), Frishammar and Hörte (2005) as well as Madrid-Guijarro, García and Van Auken (2009).

Additionally, in order to evaluate reliability and validity of the scale of innovation, a Factorial Correspondence Analysis (FCA) of second order was carried out by using the method of maximum likelihood with the software EQS 6.1 (Bentler, 2005; Brown, 2006; Byrne, 2006). The reliability of the scale was evaluated by means of Cronbach's alpha and the Composite Reliability Index (CRI) proposed by Bagozzi \& Yi (1988). The results obtained are shown in Table 1 and they indicate that the model has a good adjustment of data $\left(S-B X^{2}=10.832 ; d f\right.$ $=8 ; p=0.000 ; N F I=0.991 ; N N F I=0.995 ; C F I=0.998 ; R M S E A=0.032)$ and the values of both Cronbach's alpha and the CRI are above 0.7 which provides evidence of reliability and it justifies the internal reliability of the scale of the theoretical model (Nunally \& Bernstein, 1994; Hair et al., 1995).

Table 1. Internal consistency and convergent validity of the theoretical model

\begin{tabular}{|c|c|c|c|c|c|c|}
\hline Variable & Indicator & $\begin{array}{l}\text { Factorial } \\
\text { Loading }\end{array}$ & $\begin{array}{l}\text { Robust } \\
\text { t-Value }\end{array}$ & $\begin{array}{c}\text { Cronbach's } \\
\text { Alpha }\end{array}$ & CRI & EVI \\
\hline \multirow{2}{*}{$\begin{array}{l}\text { Product Innovation } \\
(\text { F1) }\end{array}$} & INS1 & $0.910 * * *$ & $1.000^{\mathrm{a}}$ & \multirow{2}{*}{0.842} & \multirow{2}{*}{0.843} & \multirow{2}{*}{0.730} \\
\hline & INS2 & $0.795 * * *$ & 17.929 & & & \\
\hline \multirow{2}{*}{$\begin{array}{c}\text { Process Innovation } \\
(\text { F2) }\end{array}$} & INP1 & $0.849 * * *$ & $1.000^{\mathrm{a}}$ & \multirow{2}{*}{0.768} & \multirow{2}{*}{0.770} & \multirow{2}{*}{0.628} \\
\hline & INP2 & $0.728 * * *$ & 16.519 & & & \\
\hline Management System & ISG1 & $0.734 * * *$ & $1.000^{\mathrm{a}}$ & \multirow{3}{*}{0.851} & \multirow{3}{*}{0.852} & \multirow{3}{*}{0.659} \\
\hline Innovation & ISG2 & $0.796 * * *$ & 13.616 & & & \\
\hline (F3) & ISG3 & $0.897 * * *$ & 15.385 & & & \\
\hline \multirow{3}{*}{ Innovation Activities } & F1 & $0.998 * * *$ & 12.530 & \multirow{3}{*}{0.918} & \multirow{3}{*}{0.919} & \multirow{3}{*}{0.797} \\
\hline & F2 & $0.990 * * *$ & 11.204 & & & \\
\hline & F3 & $0.643 * * *$ & 9.186 & & & \\
\hline \multicolumn{7}{|c|}{$S-B X^{2}(\mathrm{df}=8)=10.382 ; \mathrm{p}<0.000 ; \mathrm{NFI}=0.991 ; \mathrm{NNFI}=0.995 ; \mathrm{CFI}=0.998 ;$ RMSEA $=0.032$} \\
\hline
\end{tabular}


The results of second order of the AFC indicate that all items of the related factors are significant as evidence of the convergent validity $(\mathrm{p}<0.01)$. The size of all the standardized factorial loads are above 0.60 (Bagozzi \& Yi, 1988) and the Extracted Variance Index (EVI) of each pair of constructs of the theoretical model has a value above 0.50 as it has been established by Fornell \& Larcker (1981). These values indicate that the theoretical model has a good adjustment of data.

\section{Results}

A model of structural equations of second order was used in order to answer the hypotheses stated in this research paper by using the software EQS 6.1 (Bentler, 2005; Brown, 2006; Byrne, 2006). Moreover, the nomological validity was analyzed through the square Chi test which was used on the comparison of the results obtained between the theoretical model and the measurement model; the results were not significant which provides an explanation of the relations observed between the latent constructs (Anderson \& Gerbing, 1988; Hatcher, 1994). Table 2 shows the results obtained.

Table 2. Results of the structural equation model of the theoretical model

\begin{tabular}{lcccc}
\hline \multicolumn{1}{c}{ Hypothesis } & \multicolumn{1}{c}{ Structural Relationship } & $\begin{array}{c}\text { Standardized } \\
\text { Coefficient }\end{array}$ & $\begin{array}{c}\text { Robust } \\
\text { t-Value }\end{array}$ \\
\hline $\begin{array}{l}\text { H1: Higher product innovation, } \\
\text { higher innovation activities. }\end{array}$ & Product Inn. $\rightarrow \quad$ Innovation A. & $0.998 * * *$ & 12.530 \\
\hline $\begin{array}{l}\text { H2: Higher process innovation, } \\
\text { higher innovation activities. }\end{array}$ & Process Inn. $\rightarrow \quad$ Innovation A. & $0.990 * * *$ & 11.204 \\
\hline $\begin{array}{l}\text { H3: Higher manegement } \\
\text { system innovaiton, higher } \\
\text { innovation activities. }\end{array}$ & Management S.I. $\rightarrow \quad$ Innovation A. & $0.643 * * *$ & 9.186 \\
\hline & & & & \\
\hline$* * *=\mathrm{P}<0.01$ &
\end{tabular}

The results obtained from the implementation of the model of structural equations of second order are presented in Table 2. These results indicate that, regarding hypothesis $\mathbf{H}_{\mathbf{1}}(\beta=0.998, \mathrm{p}<0.01)$, the innovation in products is a good indicator for the measurement of the innovation activities of family SMEs. Regarding the second hypothesis $\mathbf{H}_{2}$, the results obtained $(\beta=0.990, \mathrm{p}<0.01)$ show that the innovation in processes is also a good indicator for the measurement of innovation activities. Regarding the third and last hypothesis stated $\mathbf{H}_{3}$, the results obtained $(\beta=0.643, \mathrm{p}<0.01)$ indicate that, similarly to the other ones, the innovation in management systems is also an excellent indicator for the measurement of the innovation activities. In conclusion, it is possible to assert that the innovation activities in products, processes and management systems are three essential indicators to measure the innovation activities in family SMEs.

\section{Discussion}

The results obtained in this empirical research allow us to conclude in three main aspects. Firstly, the innovation in products made by family businesses is more significant than the other two types of innovation. This means that the small family enterprises are more concerned and focused in the adoption and implementation of innovation activities in products which can be understandable if we consider that the markets where they participate this type of organizations are increasingly more globalized and competitive. This implies that family enterprises have to make substantial changes or improvements to their products and even create or develop new products not only to stay in the markets but also to survive in them.

Secondly, it is also possible to conclude that once the products have been improved or new ones have been created, small family enterprises can now focus in the improvement of the production processes of their products since the changes, improvements or the creation of new products require an adaptation of the processes to improve significantly their production. Otherwise, if small family enterprises do not have the capacity to improve their production processes, then the costs of creating new products or improved ones will increase significantly. This can reduce greatly not only the level of sales of the organization but also the results obtained, including the level of growth and the business return.

Thirdly, it is possible to conclude that once the small family businesses have improved or created new products and have made the corresponding and necessary changes or improvements in their products, then managers have the means to implement management systems of innovation activities. This is logical since it is not possible to manage inno vation of new products when they have not been made yet, but it is also important to notice that this is the weakest innovation activity in small family enterprises since this type of organizations have not been able to manage their innovations adequately. This is because most of the family enterprises do not copy right the intellectual property of their innovations, allowing with this that their main competitors copy their innovations. 
On the other hand, the results obtained in this empirical research contain a series of implications for those small family enterprises that have decided to adopt and implement innovation activities. Therefore, managers have to take care of the changes or improvements of the existing products in the enterprise or the creation of new products as well as the change or improvement of the production processes of new or improved products and their management systems. Otherwise, if they only focus in the improvement or development of new products, then it will be very complicated that small family businesses can obtained the expected results and bigger competitive advantages than their main competitors.

In this regard, managers of small family businesses will have to give the same importance to the three innovation activities because if they make the changes or improvements to existing or new products then they will have to work in the changes or improvements in the production processes of the new or improved products. In addition, managers of enterprises have to design management schemes of new products. If it is not possible to work simultaneously with the three innovation activities then the results that the small family enterprises can obtain will hardly have the expected impact in the significant improvement in the level of sales, the level of competitiveness and the level of business return.

Moreover, for the implementation of innovation activities to have the expected results by the managers they have to create the necessary conditions inside the organizations to have a working environment that promotes and values the creation and development of new ideas, not only to improve or create new products but also for the improvement of all the operational and management processes. The development of these actions will make a change in the cultural organization of small family businesses because it is not possible to implement innovation activities in enterprises that have a traditional culture. It is necessary a change in the organization and create an innovative culture where executives, employees and workers of small enterprises are willing to work together and share ideas and skills to improve significantly the organization.

Finally, if small family enterprises want to achieve a change in their organizational culture it will be necessary that the executives develop and implement a formal and informal training program for all the staff of the company as it will be very important that both employees and workers have an adequate training to work as a team, share their knowledge, skills and experience. In this way, new knowledge could be created inside the organization and it could be used not only in the improvement or creation of new products that is demanded by the market where this type of enterprises participate but also in the improvement or creation of production processes and management systems needed for these products.

Additionally, this empirical research has a series of limitations that are important to consider. Thus, the first limitation is the one regarding the sample as only the small family businesses that had between five and 250 workers were considered. That is why future investigations will have to consider those enterprises with less than five workers that represent more than $60 \%$ of small and medium-sized enterprises in Mexico in order to confirm the results obtained. The second limitation is that the questionnaire to collect the data was applied only to small family businesses in the state of Aguascalientes; future researches will need to apply it other states of the country and even other countries in order to verify if the results obtained are similar.

A third limitation is the scale used to measure the innovation activities since only three dimensions or factors (innovation in products, processes and management systems) and seven items were considered for the measurement. The following investigations will need to use other scales with different dimensions to confirm the results obtained. A fourth limitation is that only qualitative variables were considered to measure the innovation activities so in the future it will be necessary to use quantitative variables such as the quantity of registered products or the investment made in research and development to prove if there are any significant differences in the results obtained.

A fifth limitation is that the instrument to collect data was applied only to the managers of small family businesses. This created the assumption in the research paper that these executives had the general knowledge about innovation activities that the organization carried out in the last two years. Future research will need to apply the same questionnaire to the staff members of the enterprises and the consumers in order to confirm the results obtained. Finally, the last limitation is that high percentage of small family businesses considered that the information requested was confidential so the results obtained do not necessarily reflect the reality that this type of enterprises have.

\section{References}

Aghion, P., Burguess, R., Redding, S., \& Zilibotti, F. (2005). Entry liberalization and inequality in industrial performance. Journal of the European Economic Association, 3(1), 291-302. https://doi.org/10.1162/jeea.2005.3.2-3.291 
Anderson, J., \& Gerbing, D. (1988). Structural equation modeling in practice: a review and recommended two-step approach. Psychological Bulletin, 13(1), 411-423. https://doi.org/10.1037/0033-2909.103.3.411

Anderson, R. C., \& Reeb, D. M. (2003). Founding-family ownership and firm performance: Evidence from the S\&P 500. Journal of Finance, 58(1), 1301-1328. https://doi.org/10.1111/1540-6261.00567

Astrachan, J. (2010). Strategy in family business: Toward a multidimensional research agenda. Journal of Family Business Strategy, 1(1), 6-14. https://doi.org/10.1016/j.jfbs.2010.02.001

Ayyagari, M., Demirgüç-Kunt, A., \& Maksimovic, V. (2011). Firm innovation in emerging markets: The role of finance, governance, and competition. Journal of Finance and Quantitative Analysis, 46(2), 1545-1580. https://doi.org/10.1017/S0022109011000378

Bagozzi, R. P., \& Yi, Y. (1988). On the evaluation of structural equation models. Journal of the Academy of Marketing Science, 16(1), 74-94. https://doi.org/10.1007/BF02723327

Belloc, F. (2012). Corporate governance and innovation: A survey. Journal of Economic Surveys, 26(1), 835-864. https://doi.org/10.1111/j.1467-6419.2011.00681.x

Bentler, P. (2005). EQS 6 Structural Equations Program Manual. Encino, CA: Multivariate Software.

Block, J. H. (2012). R\&D investments in family and founder firms: An agency perspective. Journal of Business Venturing, 27(1), 248-265. https://doi.org/10.1016/j.jbusvent.2010.09.003

Blundell, R., Griffith, R., \& Van Reenen, J. (1999). Market share, market value and innovation in a panel of British manufacturing firms. Review of Economic Studies, 66(2), 529-554. https://doi.org/10.1111/1467-937X.00097

Brines, S., Shepherd, D., \& Woods, C. (2013). SME family business innovation: Exploring new combinations. Journal of Family Business Management, 3(2), 117-135. https://doi.org/10.1108/JFBM-01-2012-0002

Brouthers, K. D., Andriessen, F., \& Nicoleas, I. (1998). Driving blind: Strategic decision making in small companies. Long Range Planning, 31(1), 130-138. https://doi.org/10.1016/S0024-6301(97)00099-X

Brown, T. (2006). Confirmatory Factor Analysis for Applied Research. New York, NY: The Guilford Press.

Byrne, B. (2006). Structural Equation Modeling with EQS, Basic Concepts, Applications, and Programming. 2th Edition. London; LEA Publishers.

Chen, H. L., \& Hsu, W. T. (2009). Family ownership, broad independence, and R\&D investment. Family Business Review, 22(1), 347-362. https://doi.org/10.1177/0894486509341062

Cho, H. J., \& Pucik, V. (2005). Relationship between innovativeness, quality, growth, profitability, and market value. Strategic Management Journal, 26(2), 555-575. https://doi.org/10.1002/smj.461

Choi, S. B., Lee, S. H., \& Williams, C. (2011). Ownership and firm innovation in a transition economy: Evidence from China. Research Policy, 40(1), 441-452. https://doi.org/10.1016/j.respol.2011.01.004

Chua, J. H., Chrisman, J. J., \& Sharma, P. (1999). Defining the family business by behavior. Entrepreneurship Theory and Practice, 23(4), 19-30. https://doi.org/10.1177/104225879902300402

Cohen, W. M., \& Klepper, S. (1996). A reprise of size and R\&D. Economic Journal, 106(3), 925-951. https://doi.org/10.2307/2235365

Craig, J., \& Dibrell, C. (2006). 1 Family Business Review, 18(2), 105-122. https://doi.org/10.1111/j.1741-6248.2005.00035.x

Craig, J., \& Moores, K. (2006). A 10-year longitudinal investigation of strategy, systems, and environment on innovation family firms. Family Business Review, 19(1), 1-10. https://doi.org/10.1111/j.1741-6248.2006.00056.x

Cramer, L. (2002). Social Representation of Entrepreneurial Action. Master Dissertation. Lavras, Minas Gerai, Brazil: UFLA.

Dyer, W. (2006). Examining the "family effect" on firm performance. Family Business Review, 19(4), 253-273. https://doi.org/10.1111/j.1741-6248.2006.00074.x

Emmendoerfer, M. L., \& Helal, D. H. (2008). Family business: A space for generation ideas and products. In Carrieri, A.P., Saraiva, L.S. and Grzyboviski, D. (Eds.), Family Business: A Mosaic in Brazil. Passo Fundo: University of Passo Fundo.

Fornell, C., \& Larcker, D. (1981). Evaluating structural equation models with unobservable variables and 
measurement error. Journal of Marketing Research , 18(1), 39-50. https://doi.org/10.2307/3151312

Frishammar, J., \& Hörte, S. (2005). Managing external information in manufacturing firms: The impact of innovation performance. Journal of Product Innovation Management, 22(1), 251-266. https://doi.org/10.1111/j.0737-6782.2005.00121.x

Gudmundson, D., Hartman, E., \& Tower, C. (2003). Innovation in small business: Culture and ownership structure do matter. Journal of Development Entrepreneurship, 8(1), 1-17.

Habbershon, T. (2006). Commentary: A framework for managing the familiness and agency advantages in family firms. Entrepreneurship Theory and Practice, 30(6), 879-886.

https://doi.org/10.1111/j.1540-6520.2006.00158.x

Habbershon, T., Williams, M., \& MacMillan, I. (2003). A unified systems perspective of family firm performance. Journal of Business Venturing, 18(4), 452-465. https://doi.org/10.1016/S0883-9026(03)00053-3

Hair, J. F., Anderson, R. E., Tatham, R. L., \& Black, W. C. (1995). Multivariate Data Analysis with Readings. New York, NY: Prentice-Hall.

Handler, W. C. (1994). Succession in family business: A review of the research. Family Business Research, 7(2), 133-158. https://doi.org/10.1111/j.1741-6248.1994.00133.x

Hatcher, L. (1994). A Step by Step Approach to Using the SAS System for Factor Analysis and Structural Equation Modeling, Cary, NC: SAS Institute Inc.

James, H. S. (1999). Owner as manager, extended horizons and the family firm. International Journal of the Economics of Business, 6(1), 41-55. https://doi.org/10.1080/13571519984304

Kalantaridis, C., \& Pheby, J. (1999). Processes of innovation among manufacturing SMEs: The experience of Bedfordshire. Entrepreneurship and Regional Development, 11(2), 57-78. https://doi.org/10.1080/089856299283290

Kellermanns, F. W., \& Eddleston, K. (2006). Corporate entrepreneurship in family firms: A family perspective. Entrepreneurship Theory and Practice, 30(6), 809-830. https://doi.org/10.1111/j.1540-6520.2006.00153.x

Kellermanns, F. W., Eddleston, K., Sarathy, R., \& Murphy, F. (2012). Innovativeness in family firms: A family influence perspective. Small Business Economics, 38(1), 85-101. https://doi.org/10.1007/s11187-010-9268-5

Khanna, T., \& Palepu, K. (2000a). The future of business groups in emerging markets: Long-run evidence from Chile. Academy of Management Journal, 43(2), 268-285. https://doi.org/10.2307/1556395

Khanna, T., \& Palepu, K. (2000b). Is group affiliation profitable in emerging markets? An analysis of diversified Indian business groups. Journal of Finance, 55(3), 867-891. https://doi.org/10.1111/0022-1082.00229

Kim, H., Kim, H., \& Lee, P. M. (2008). Ownership structure and the relationship between financial slack and R\&D investments: Evidence from Korean firms. Organization Science, 19(2), 404-418. https://doi.org/10.1287/orsc. 1080.0360

Kraus, S., Pohjola, M., \& Koponen, A. (2012). Innovation in family firms: An empirical analysis linking organizational and managerial innovation to corporate success. Review of Managerial Science, 6(3), 265-286. https://doi.org/10.1007/s11846-011-0065-6

La Porta, R., Lopez-de-Silanes, F., \& Shleifer, A. (1999). Corporate ownership around the world. Journal of Finance, 54(2), 471-517. https://doi.org/10.1111/0022-1082.00115

Laforet, S. (2013). Innovation characteristics of young and old family-owned businesses. Journal of Small Business and Enterprise Development, 20(1), 204-224. https://doi.org/10.1108/14626001311298493

Le Breton-Miller, I., \& Miller, D. (2008). To grow or to harvest: Governance, strategy and performance in family and lone founder firms. Journal of Strategy and Management, 1(1), 41-56. https://doi.org/10.1108/17554250810909419

Le Breton-Miller, I., Miller, D., \& Lester, R. H. (2011). Stewardship or agency? A social embeddedness reconciliation of conduct and performance in public family businesses. Organizations Science, 22(3), 704-721. https://doi.org/10.1287/orsc. 1100.0541

Lee, P. M., \& O’Neil, H. M. (2003). Ownership structure and R\&D investments of U.S. and Japanese firms. Agency and stewardship perspectives. Academy of Management Journal, 46(1), 212-225. 
https://doi.org/10.2307/30040615

Lima, J. B. (2010). Entrepreneurial actions and practice in entrepreneurship. In. Gimenez, F., Morais, J. and Ramos, S. (Eds.), Entrepreneurial Small Business Strategy. Curitiba: Compagnat.

Litz, R. (1995). The family business: To ward definitional clarity. Proceedings of the Academy of Management, 100-104.https://doi.org/10.5465/AMBPP.1995.17536337

Litz, R. A., \& Kleysen, R. F. (2001). Your old men shall dream dreams, your young men shall see visions: Toward a theory of family firm innovation with help from Brubeck family. Family Business Review, 14(4), 335-352. https://doi.org/10.1111/j.1741-6248.2001.00335.x

Lodh, S., Nandy, M., \& Chen, J. (2014). Innovation and family ownership: Empirical evidence from India. Corporate Governance: An International Review, 22(1), 4-23. https://doi.org/10.1111/corg.12034

Madrid-Guijarro, A., Garcia, D., \& Van Auken, H. (2009). Barriers to innovation among Spanish manufacturing SMEs. Journal of Small Business Management, 47(4), 465-488. https://doi.org/10.1111/j.1540-627X.2009.00279.x

Manikutty, S. (2000). Family business groups in India: A resource-based view of the emerging trends. Family Business Review, 13(1), 279-292.

McAdam, R., Reid, R., \& Mitchell, N. (2010). Longitudinal development of innovation implementation in family-based SMEs: The effects of critical incidents. International Journal of Entrepreneurial Behaviour \& Research, 16(5), 437-456. https://doi.org/10.1108/13552551011071887

Morck, R., \& Yeung, B. (2003). Agency problems in large family business. Entrepreneurship Theory and Practice, 27(2), 367-382. https://doi.org/10.1111/1540-8520.t01-1-00015

Naldi, L., Nordqvist, M., Sjoberg, K., \& Wiklund, J. (2007). Entrepreneurial orientation, risk taking and performance in family firms. Family Business Review, 20(1), 33-47. https://doi.org/10.1111/j.1741-6248.2007.00082.x

Nordqvist, M., Habbershon, T., \& Melin, L. (2008). Transgenerational entrepreneurship: Exploring entrepreneurial orientation in family firms. In Landstrom, H., Smallbone, D., Crijns, H., and Lavern, E. (Eds.), Entrepreneurship, Sustainable Growth and Performance: Frontiers in European Entrepreneurship Research. London: Edward Elgar Publishing. https://doi.org/10.4337/9781848443952.00014

Nunnally, J. C., \& Bernstein, I. H. (1994). Psychometric Theory. $3^{\text {a }}$ Edition. New York, NY: McGraw-Hill.

Richbell, S., Watts, H., \& Wardle, P. (2006). Owner managers and business planning in the small firms. International Small Business Journal, 24(5), 496-514. https://doi.org/10.1177/0266242606067275

Salvato, R. (2004). Predictors of entrepreneurship in family firms. Journal of Private Equity, 7(3), 68-76. https://doi.org/10.3905/jpe.2004.412339

Sharma, P. (2004). An overview of the field of family business studies: Current status and directions for the future. Family Business Review, 17(1), 1-36. https://doi.org/10.1111/j.1741-6248.2004.00001.x

Sharma, P., \& Salvato, C. (2011). Commentary: Exploiting and exploring new opportunities over life cycle stages on family firms. Entrepreneurship Theory and Practice, 35(6), 1199-1205. https://doi.org/10.1111/j.1540-6520.2011.00498.x

Sharma, P., Chrisman, J.J., \& Chua, J.H. (1997). Strategic management of the family business: Past research and future challenges. Family Business Review, 10(1), 1-35. https://doi.org/10.1111/j.1741-6248.1997.00001.x

Shleifer, A., \& Vishny, R. W. (1986). Large shareholders and corporate control. Journal of Political Economy, 94(3), 461-488. https://doi.org/10.1086/261385

Sirmon, D. G., \& Hitt, M. A. (2003). Managing resources: Linking unique resources, management, and wealth creation in family firms. Entrepreneurship Theory and Practice, 27(2), 339-358. https://doi.org/10.1111/1540-8520.t01-1-00013

Sirmon, D. G., Arregle, J. L., Hitt, M. A., \& Webb, J. W. (2008). The role of family influence in firms' strategic responses to threat of imitation. Entrepreneurship Theory and Practice, 32(3), 979-998. https://doi.org/10.1111/j.1540-6520.2008.00267.x

Upton, N., \& Heck, R. K. Z. (1997). The family business dimension of entrepreneurship. In Sexton, D.L. and Smilor, R.A. (Eds.), Entrepreneurship 2000. Chicago: Upstart Publishing. 
Upton, N., Teal, E. J., \& Felan, J. T. (2001). Strategic and business planning practices of fast growth family firms. Journal of Small Business Management, 39(1),60-72. https://doi.org/10.1111/0447-2778.00006

Villalonga, B., \& Amit, R. (2006). How do family ownership, control and management affect firm value? Journal of Financial Economics, 80(1), 385-417. https://doi.org/10.1016/j.jfineco.2004.12.005

Wortman, M. S. (1994). Theoretical foundations for family-owned business: A conceptual and research-based paradigm. Family Business Review, 7(1), 3-27. https://doi.org/10.1111/j.1741-6248.1994.00003.x

Zahra, S. (2005). Entrepreneurial risk taking in family firms. Family Business Review, 18(1), 23-43. https://doi.org/10.1111/j.1741-6248.2005.00028.x

Zahra, S., \& Covin, J. (1993). Business strategy, technology policy and firm performance. Strategic Management Journal, 14(6), 451-478. https://doi.org/10.1002/smj.4250140605

Zellweger, T., Muhlebach, C., \& Sieger, P. (2010). How much and what kind of entrepreneurial orientation is needed for family business continuity? In Nordqvist, M. and Zellweger, T. (Eds.), Transgenerational Entrepreneurship: Exploring Growth and Firm Performance in Family Firms Across Generations. London: Edward Elgar Publishing. https://doi.org/10.4337/9781849805469.00016

\section{Copyrights}

Copyright for this article is retained by the author(s), with first publication rights granted to the journal.

This is an open-access article distributed under the terms and conditions of the Creative Commons Attribution license (http://creativecommons.org/licenses/by/4.0/). 